Journal of Telenursing (JOTING)

Volume 3, Nomor 1, Juni 2021

e-ISSN: 2684-8988

p-ISSN: 2684-8996

DOI: https://doi.org/10.31539/joting.v3i1.2114

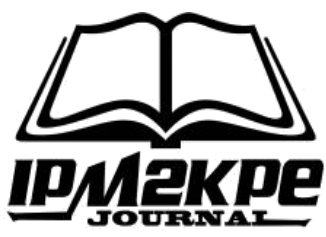

\title{
SIKAP ORANG TUA DENGAN KEJADIAN OBESITAS PADA ANAK USIA 6-12 TAHUN
}

\author{
Mochamad Heri ${ }^{1}$, Komang Gde Trisna Purwantara ${ }^{2}$, Ni Made Dwi Yunica Astriani ${ }^{3}$, \\ I Dewa Ayu Rismayanti ${ }^{4}$ \\ Sekolah Tinggi Ilmu Kesehatan Buleleng ${ }^{1,2,3,4}$ \\ mochamad_heri@rocketmail.com ${ }^{1}$
}

\begin{abstract}
Penelitian ini bertujuan untuk mengetahui hubungan sikap orang tua dengan kejadian obesitas pada anak usia 6-12 tahun di SD Negeri 1 Banyuasri. Jenis penelitian ini adalah deskriptif korelasional dengan pendekatan cross-sectional. Hasil penelitian ini menunjukkan bahwa orang tua yang memiliki sikap positif terhadap obesitas pada anak usia 6-12 tahun adalah sebanyak 24 orang $(53,3 \%)$ dengan anak yang mengalami obesitas sebanyak enam orang (13,3\%). Hasil analisa data dengan uji Chi-Square memperoleh nilai 0,000 atau $p<\alpha(0,05)$. Simpulan, ada hubungan yang bermakna antara sikap orang tua dengan kejadian obesitas pada anak usia 6-12 tahun di SD Negeri 1 Banyuasri.
\end{abstract}

Kata Kunci: Anak Usia 6-12 Tahun, Obesitas, Sikap Orang Tua

\section{ABSTRACT}

This study aims to determine the relationship between parent's attitudes and the incidence of obesity in children aged 6-12 years at SD Negeri 1 Banyuasri. This type of research is descriptive correlational with a cross-sectional approach. This study indicates that 24 people (53.3\%) have a positive attitude towards obesity in children aged 6-12 years with six (13.3\%) obese children. Data analysis results with the ChiSquare test obtained a value of 0.000 or $p<\alpha(0.05)$. In conclusion, there is a significant relationship between parent's attitudes and the incidence of obesity in children aged 612 years at SD Negeri 1 Banyuasri.

Keywords: Children 6-12 Years, Obesity, Parent's Attitudes

\section{PENDAHULUAN}

Obesitas adalah permasalahan umum yang dialami anak-anak pada masa sekarang. Obesitas didefinisikan sebagai suatu kelainan yang ditandai dengan penimbunan jaringan lemak tubuh secara berlebihan. Sebutan The New World Syndrome diberikan untuk obesitas yang telah menjadi suatu epidemi global di seluruh dunia. Sampai saat ini obesitas merupakan masalah yang sulit untuk diatasi karena merupakan masalah yang kompleks dan penyebabnya multifaktor (Al Rahmad, 2019). Data yang dikumpulkan dari berbagai negara prevalensi obesitas pada anak usia 6-12 tahun di Rusia adalah $10 \%$, di Cina 3,4\% dan di Inggris $10-17 \%$, bergantung pada umur dan jenis kelamin. Penelitian yang dilakukan di Malaysia akhir-akhir ini menunjukan bahwa prevalensi obesitas mencapai 6,6\% untuk kelompok umur 7 tahun dan menjadi 13,8\% 
pada kelompok umur 10 tahun. Prevalensi obesitas pada anak umur 6-14 tahun di Jepang berkisar antara 5\% sampai dengan $11 \%$. Hal ini terkait dengan perubahan dalam pola makan, perkembangan teknologi dan sosial ekonomi serta perubahan gaya hidup yang terjadi di beberapa negara (Jannah \& Utami, 2018).

Perubahan gaya hidup yang menjurus ke westernisasi dan pola hidup kurang gerak (sedentary) sering ditemukan di kota-kota besar di Indonesia. Perubahan gaya hidup ini menyebabkan perubahan pengetahuan dan sikap, terutama sikap orang tua terhadap anaknya dalam pola makan, pemilihan makanan yang merujuk pada pola makan tinggi kalori, lemak dan kolestrol. Selain itu, faktor lain yang menyebabkan kejadian obesitas pada anak adalah heredity dan pola asuh orang tua (Setyawaty et al., 2020).

Sikap adalah suatu proses penilaian yang dilakukan seseorang terhadap suatu objek atau situasi yang disertai adanya perasaan tertentu dan memberikan dasar kepada orang tersebut untuk membuat respon atau berperilaku dalam cara tertentu. Sikap orang tua sangat diharapkan untuk mencegah obesitas pada anak. Orang tua sangat berperan penting karena faktor risiko obesitas dapat dihambat dan dicegah apabila orang tua telah menyadari sejak dini bahwa anaknya berpotensi terkena obesitas. Pengontrolan dan pengawasan orang tua terhadap keseharian perilaku, pola hidup anak harus memuat unsur kesehatan fisik maupun psikis. Pola aktivitas dan pola makan yang tidak dipantau oleh orang tua akan meningkatkan berbagai macam penyakit akibat obesitas pada anak (Maesarah et al., 2019).

Kegemukan atau obesitas merupakan salah satu masalah kesehatan utama di dunia, tidak saja terjadi pada orang dewasa namun juga terjadi pada anak-anak dimana sudah menjadi epidemi global yang harus segera ditangani, serta penyebab kematian kelima yang serius di dunia, sehingga meningkatnya resiko terjadinya penyakit degeneratif dan kematian. Obesitas adalah menumpuknya lemak berlebih atau abnormal yang dapat mengganggu kesehatan, kasus obesitas terjadi tidak hanya pada orang dewasa namun juga anak-anak (Sety et al., 2021).

Anak-anak yang mengalami obesitas banyak tinggal di negara berkembang, dimana peningkatanya 30\% lebih tinggi dari pada negara maju. Pendapatan keluarga yang tinggi serta uang saku anak, cenderung pola makan anak pun menjadi berubah, dimana terjadi peningkatan asupan lemak, protein hewani dan gula. Keluarga dengan pendapatan rendah cenderung memiliki kebiasaan aktifitas dan pola makan yang baik, dimana anak dengan keluarga pendapatan rendah lebih banyak melakukan aktivitas di luar rumah dan memiliki pola makan yang tidak mengkonsumsi makanan tinggi lemak, serta jarang mengkonsumsi makanan cepat saji (Setyawaty et al., 2020).

Perkembangan pada anak meliputi beberapa aspek, salah satunya yaitu aspek fisik. Pertumbuhan dan perkembangan merupakan suatu hal yang sangat penting bagi mahluk hidup yaitu sebagai upaya untuk mempertahankan kelangsungan hidup dan melestarikan keturunan. Kelompok anak yang beresiko tinggi mengalami obesitas rentang usia 6-12 tahun, dampak obesitas bagi kesehatan berkaitan dengan penyakit serius sehingga kejadian obesitas ini perlu mendapatkan perhatian khusus dan dilakukan pencegahan sedini mungkin karena jika dibiarkan akan terus mengganggu generasi penerus (Heri \& Ariana, 2018).

Obesitas pada saat usia sebelum dewasa akan memberi peluang untuk obesitas saat usia dewasa. Bila saat usia 7 tahun obesitas, maka peluang obesitas saat usia dewasa adalah sebanyak $40 \%$ dan bila usia remaja obesitas maka peluang gemuk saat usia dewasa adalah 70\%. Saat ini lebih dari sembilan juta anak di dunia berusia enam 
tahun ke atas mengalami obesitas, obesitas semakin meningkat dikalangan anak-anak hingga kini angkanya terus melonjak dua kali lipat pada anak usia 6-11 tahun (Miranda et al., 2020).

Berdasarkan hasil studi pendahuluan yang dilakukan oleh peneliti mengenai berat badan, tinggi badan serta keadaan fisik/bobot tubuh anak di SD Negeri 1 Banyuasri pada tanggal 28 Januari 2016, keseluruhan anak dari kelas I sampai dengan kelas VI menunjukkan bahwa anak yang mengalami obesitas adalah sebanyak 50 anak dari jumlah siswa keseluruhan yaitu 267 orang. Selanjutnya dari 50 orang anak tersebut diambil secara acak sebanyak 10 orang, dilakukan kembali pengukuran berat badan, tinggi badan didapatkan anak mengalami obesitas sebanyak lima orang dengan penghitungan indeks massa tubuh (IMT) dan dominan terjadi pada anak usia 9-11 tahun. Diantara orang tua dari anak-anak yang mengalami obesitas yang diwawancara, rata-rata mengatakan bahwa mereka tidak terlalu membatasi anak untuk mengkonsumsi makanan/jajanan apa saja.

Penelitian yang di lakukan oleh Al Rahmad (2019) menyimpulkan sedentari merupakan faktor risiko terhadap kejadian obesitas pada anak sekolah dasar. Penelitian lain yang di lakukan oleh Noviyani et al., (2018) menunjukkan bahwa pola makan memiliki hubungan dengan perkembangan anak dimana orang tua yang memiliki tingkat pengetahuan yang baik tentang pola makan akan mampu untuk memantau dan melatih anak untuk perkembangan dengan optimal. Adapun menurut Livana et al., (2018) mayoritas pola asuh yang dilakukan orang tua pada anak usia sekolah dengan obesitas adalah menggunakan pola asuh demokratis.

Berdasarkan hasil analisis penelitian terdahulu, sejauh ini belum ada spesifikasi terkait sikap orang tua dengan kejadian obesitas pada anak usia 6-12 tahun. Oleh karena itu, peneliti tertarik untuk melakukan kajian ini guna mengetahui hubungan sikap orang tua dengan kejadian obesitas pada anak usia 6-12 tahun di SD Negeri 1 Banyuasri.

\section{METODE PENELITIAN}

Jenis penelitian ini adalah non eksperimen yaitu deskriptif korelasional dengan menggunakan pendekatan cross sectional. Populasi dalam penelitian ini adalah anak usia 6-12 tahun yang mengalami obesitas di SD Negeri 1 Banyuasri sebanyak 50 anak. Penentuan sampel dengan teknik purposive sampling. Sampel dalam penelitian ini adalah seluruh anak usia 6-12 tahun yang masuk kriteria inklusi yaitu sebanyak 45 anak dan orang tua dari masing-masing anak tersebut. Instrumen yang digunakan dalam penelitian ini adalah lembar observasi untuk mengukur obesitas dengan menggunakan timbangan berat badan dan Microtoise serta menggunakan kuesioner untuk sikap orang tua.

Pelaksanaan penelitian dilakukan di wilayah kerja puskesmas Buleleng 1 pada bulan September-Oktober 2020. Lokasi penelitian adalah di SD Negeri 1 Banyuasri, Buleleng, Propinsi Bali serta mengujungi rumah orang tua dari masing-masing responden (anak) untuk melakukan penyebaran kuesioner untuk sikap orang tua. 


\section{HASIL PENELITIAN}

\section{Analisis Univariat}

\section{Karakteristik Responden}

Tabel. 1

Distribusi Frekuensi Responden Berdasarkan Jenis Kelamin di SD Negeri 1 Banyuasri

\begin{tabular}{ccc}
\hline Jenis Kelamin & Frekuensi & Presentase (\%) \\
\hline Perempuan & 21 & 46.7 \\
Laki-laki & 24 & 53.3 \\
\hline Total & 45 & 100.0 \\
\hline
\end{tabular}

Berdasarkan tabel 1, dapat dilihat bahwa dari 45 responden sebagian besar responden dengan jenis kelamin laki-laki yaitu 24 responden $(53.3 \%)$ dan sebagian kecil dengan dengan jenis kelamin perempuan yaitu 21 responden (46.7\%).

Tabel. 2

Distribusi Responden Berdasarkan Umur di SD Negeri 1 Banyuasri

\begin{tabular}{ccc}
\hline Umur Anak & Frekuensi $(\mathrm{N})$ & Persentase $(\%)$ \\
\hline 6 Tahun & 1 & 2.2 \\
7 Tahun & 2 & 4.4 \\
8 Tahun & 1 & 2.2 \\
9 Tahun & 11 & 24.4 \\
10 Tahun & 16 & 35.6 \\
11 Tahun & 10 & 22.2 \\
12 Tahun & 4 & 8.9 \\
\hline Jumlah & 45 & 100 \\
\hline
\end{tabular}

Tabel 2 menunjukan bahwa sebagian besar anak yang mengalami obesitas yaitu berumur 10 tahun sebanyak 16 orang $(35.6 \%)$ dan anak yang mengalami obesitas rendah berumur 6 dan 8 tahun sebanyak 1 orang $(2.2 \%)$.

Tabel. 3

Data Hasil Penelitian Variabel Sikap Orang Tua

\begin{tabular}{ccc}
\hline Sikap Orang Tua & Frekuensi (N) & Persentase (\%) \\
\hline Positif (>mean) & 24 & 53.3 \\
Negatif (<mean) & 21 & 46.7 \\
\hline Jumlah & 45 & 100
\end{tabular}

Data pada tabel 3 menunjukan bahwa dari 45 responden, sebagian besar orang tua dari anak memiliki sikap posistif yaitu sebanyak 24 orang $(53.3 \%)$ dan orang tua dari anak yang memiliki sikap negatif sebanyak 21 orang (46.7).

Tabel. 4

Data Hasil Penelitian Kejadian Obesitas pada Anak Usia 6-12 Tahun

\begin{tabular}{ccc}
\hline IMT Anak & Frekuensi (N) & Persentase (\%) \\
\hline Obesitas & 26 & 57.8 \\
Tidak Obesitas & 19 & 42.2 \\
\hline Jumlah & 45 & 100
\end{tabular}


Tabel 4 menunjukan bahwa dari 45 responden, sebagian besar anak mengalami obesitas yaitu sebanyak 26 orang $(57.8 \%)$ dan anak yang tidak mengalami obesitas sebanyak 19 orang (42.2).

\section{Analisis Bivariat}

Tabel. 5

Tabel Hasil Uji Contingency Coefficient

\begin{tabular}{ccc}
\hline Uji Contingency Coefficient & Value & Approx. Sig \\
\hline Nominal by Nominal Contingency Coefficient & 0.579 & 0.000 \\
\hline
\end{tabular}

Berdasarkan tabel 5, hasil analisis uji contingency coefficient dapat dilihat pada Approx. Sig. (0.000) yang berarti $\mathrm{p}<0.05$. Dengan demikian dapat disimpulkan bahwa ada hubungan yang bermakna antar sikap orang tua dengan kejadian obesitas pada anak usia 6-12 tahun SD Negeri 1 Banyuasri.

\section{PEMBAHASAN}

\section{Analisis Univariat}

Berdasarkan tabel 1, dapat dilihat dari hasil penelitian tentang karakteristik responden berdasarkan jenis kelamin anak laki-laki yang mengalami obesitas lebih banyak di dapatkan dalam penelitian ini, bisa dikarenakan anak laki-laki di zaman teknologi seperti sekarang cenderung lebih senang melakukan aktivitas yang menetap seperti bermain game. Menurut peneliti ini dikarenakan anak laki-laki cenderung lebih suka bermain game hingga berjam-jam dan anak jadi malas bergerak. Apabila diikuti dengan pola makan yang tidak terkontrol akan meningkatkan terjadinya obesitas. Di dukung penelitian sebelumnya oleh Hidayati \& Pibriyanti (2018) menyebutkan bahwa jenis kelamin dapat mempengaruhi obesitas.

Penelitian ini mendukung beberapa penelitian sebelumnya bahwa persentase obesitas di beberapa kota besar dan beberapa negara lain pada umumnya lebih tinggi pada anak laki-laki, anak laiki-laki mengalami obesitas 1.4 kali di bandingkan anak perempuan. Hal ini kemungkinan disebabkan oleh persepsi anak perempuan yang lebih sering membatasi makan untuk alasan penampilan (Suryamulyawan \& Arimbawa, 2019).

Karakteristik umur anak pada tabel 2 menunjukkan bahwa anak yang sudah mulai masuk lingkup sekolah, lingkungan pertama di luar keluarga akan mengkonsumsi makanan dan jajanan yang disukai, mulai dari memilih makanan yang manis/gurih, minuman ringan (softdrink). Menurut peneliti, masing-masing umur ada anak yang mengalami obesitas ini dapat dikarenakan anak usia 6-12 tahun sudah masuk ke lingkup sekolah, lingkungan diluar keluarga dimana anak akan mengkonsumsi makanan yang disukai terutama makanan ringan/softdrink yang dapat meningkatkan terjadinya obesitas. Sejalan dengan penelitian Suryamulyawan \& Arimbawa (2019) bahwa angka kejadian obesitas banyak ditemukan pada rentang usia lebih dari 9 tahun di bandingkan dengan usia kurang dari atau sama dengan 9 tahun.

Hasil penelitian sikap orang tua pada tabel 3 menunjukkan bahwa sikap orang tua yang positif didapatkan lebih banyak dapat dikarenakan pengetahuan/informasi yang dimiliki orang tua sehingga orang tua mengetahui bahaya obesitas dan lebih mampu mencegah terjadinya obesitas pada anak. Sebaliknya sikap orang tua yang negatif 
cenderung tidak terlalu memperhatikan pola makan/konsumsi anak setiap harinya, sehingga anak lebih beresiko mengalami obesitas.

Sikap positif seseorang bisa muncul dikarenakan pernyataan sikap mungkin berisi/mengatakan hal-hal yang positif dan bersifat mendukung tentang objek sikap. Sebaliknya sikap negatig bisa karena pernyataan bersifat negatif /tidak mendukung objek sikap. Sikap positif/negatif dari orang tua akan berpengaruh terhadap kehidupan anak-anaknya. Sikap orang tua akan dijadikan role model bagi anak (Livana et al., 2018).

Kejadian obesitas pada anak usia 6-12 tahun (tabel 4) menunjukkan bahwa anak yang mengalami obesitas lebih banyak disebabkan oleh pola konsumsi anak yang berlebih, anak sekolah di wilayah perkotaan, anak zaman sekarang suka melakukan kegiatan yang menetap seperti bermain game hingga berjam-jam, menonton televis dan anak malas bergerak. Sebaliknya anak yang tidak mengalami obesitas karena orang tua sudah mengontrol/mengawasi pola makan/aktivitas fisik anak.

Hasil penelitian ini sejalan dengan penelitian yang dilakukan oleh Sety et al., (2021) menyatakan bahwa anak usia 6-12 tahun mengalami beberapa tahap perkembangan yang salah satunya adalah perkembangan fisik. Pada tahap ini terdiri dari efek gizi pada pertumbuhan anak (kekurangan/kelebihan zat gizi akan mempengaruhi tumbuh kembang anak) dan efek gizi berlebih yang dampak nyatanya adalah terjadinya obesitas pada anak. Selain itu, obesitas pada anak apabila tidak dicegah sejak dini akan berlanjut menjadi obesitas dewasa dan akan menjadi faktor pemicu berbagai penyakit di kemudian hari baik degeneratif/kardiovaskuler.

\section{Analisis Bivariat}

Berdasarkan tabel 5, data menunjukkan nilai Approx. Sig. adalah sebesar 0.000 yang berarti $\mathrm{p}<0.05$, sehingga dapat disimpulkan ada hubungan yang bermakna antar sikap orang tua dengan kejadian obesitas pada anak usia 6-12 tahun di SD Negeri 1 Banyuasri.

Orang tua yang memiliki sikap positif anak yang mengalami obesitas lebih sedikit, sebaliknya orang tua yang memiliki sikap negatif obesitas yang terjadi pada anak lebih banyak. Menurut peneliti, kemungkinan ini dikarenakan orang tua yang mengetahui informasi tentang bahaya obesitas pada anak akan menerapkan sikap yang positif terhadap keseharian anak. Orang tua yang sudah mengetahui bahaya/pencegahan yang harus dilakukan apabila anak sudah mengalami obesitas akan menerapkan gaya hidup yang sehat dimulai dengan mengontrol/memantau pola konsumsi anak dengan memperhatikan apa yang dimakan anak setiap hari, mengajak anak melakukan aktivitas fisik seperti berolahraga secara teratur, meminimalkan perilaku menetap anak serta meminimalkan konsumsi makanan cepat saji.

Sebaliknya orang tua yang memiliki sikap negatif, cenderung lebih membiarkan anak mengkonsumsi apa saja yang anak senangi. Orang tua tidak terlalu memperhatikan berat badan anak, karena sebagian besar orang tua menganggap anak yang gemuk adalah anak yang sehat, dan belum tentu anak yang gemuk itu obesitas, sehingga orang tua akan membiarkan anaknya untuk makan secara berlebihan. Secara tidak langsung apabila orang tua menerapkan sikap yang negatif anak akan lebih berpeluang untuk mengalami obesitas. Ada hubungan antara sikap orang tua dengan kejadian obesitas pada anak usia 6-12 tahun dalam penelitian ini menunjukan, sikap orang tua baik yang positif/negatif sangat berhubungan dengan kejadian obesitas pada anak. 
Peran orang tua sangat diperlukan dalam membimbing, memberikan pengertian, mengingatkan dan menyediakan fasilitas kepada anak agar anak dapat membiasakan dalam menjaga kesehatan. Orang tau sebagai orang pertama yang bertanggung jawab terhadap kesehatan anak mengambil inisiatif memberikan semua jenis makanan yang dianggap dapat memenuhi kebutuhan gizi anak, terutama orang tua yang berpendapatan tinggi memiliki peluang lebih besar untuk memilih jenis makanan (Rompas et al., 2018).

Pernyataan tersebut didukung oleh penelitian yang dilakukan Maharani \& Hernanda (2020) bahwa beberapa faktor yang berhubungan dengan kejadian obesitas adalah pengetahuan, sikap dan faktor pendukung. Hasil penelitian menunjukan bahwa dari analisis chi-square ada hubungan yang signifikan antara aktivitas fisik dengan kejadian obesitas pada anak usia sekolah. Berfokus pada aktivitas fisik didapatkan bahwa hasil $\mathrm{p}=0,004$, sehingga dapat disimpulkan bahwa aktivitas fisik memiliki peranan penting dan berhubungan dengan kejadian obesitas.

Hasil analisa hubungan antara sikap orang tua dengan kejadian obesitas pada anak usia 6-12 tahun di SD Negeri 1 Banyuasri dari 45 responden, orang tua yang memiliki sikap positif sebanyak 24 orang $(53,3 \%)$ dengan anak yang mengalami obesitas sebanyak 6 orang $(13,3 \%)$ dan yang tidak mengalami obesitas sebanyak 18 orang $(40 \%)$, orang tua yang memiliki sikap negatif sebanyak 21 orang $(46,7 \%)$ dengan anak yang mengalami obesitas sebanyak 20 orang $(44,4 \%)$ dan yang tidak mengalami obesitas sebanyak 1 orang $(2,2 \%)$. Uji statistik Chi-Square menghasilkan nilai $\mathrm{p}=0,000$ $(\mathrm{p}<0,05)$ dengan taraf kepercayaan 95\%, sehingga dapat disimpulkan bahwa ada hubungan yang bermakna antara sikap orang tua dengan kejadian obesitas pada anak usia 6-12 tahun di SD Negeri 1 Banyuasri.

Sikap orang tua sangatlah diharapkan untuk mencegah terjadinya obesitas pada anak. Pengontrolan dan pengawasan orang tua terhadap keseharian perilaku dan pola hidup anak harus memuat unsur kesehatan fisik dan psikis. Pola aktivitas/pola makan hendaknya dipantau orang tua untuk mencegah terjadinya berbagai penyakit akibat obesitas pada anak.

\section{SIMPULAN}

Ada hubungan yang bermakna antara sikap orang tua dengan kejadian obesitas pada anak usia 6-12 tahun di SD Negeri 1 Banyuasri.

\section{SARAN}

Diharapkan kepada orang tua anak dapat melakukan pengontrolan dan pengawasan pola makan dan aktivitas fisik anak setiap harinya. Adapun bagi institusi tempat penelitian, diharapkan dapat melakukan kerja sama dengan dinas kesehatan yang terkait untuk memberikan pendidikan kesehatan mengenai bahaya dan pencegahan obesitas pada anak.

\section{DAFTAR PUSTAKA}

Al Rahmad, A. H. (2019). Keterkaitan Asupan Makanan dan Sedentari dengan Kejadian Obesitas pada Anak Sekolah Dasar di Kota Banda Aceh. Buletin Penelitian Kesehatan, 47(1), 67-76. https://doi.org/10.22435/bpk.v47i1.579

Heri, M., \& Ariana, P. A. (2018). Pengaruh Media Flashcard terhadap Kemampuan Anak Usia 3-4 Tahun di TPA Yayasan Pantisila PAUD Santo Rafael Singaraja. Jurnal Kesehatan Midwinerslion, 3(2), 221-227. 
https://ejournal.stikesbuleleng.ac.id/index.php/Midwinerslion/article/view/18

Hidayati, K. N., \& Pibriyanti, K. (2018). Anak Perempuan dan Obesitas Sebagai Faktor Risiko Kejadian Kadar Gula Darah Tinggi pada Anak Sekolah Dasar. Jurnal Gizi Indonesia (The Indonesian Journal of Nutrition), 6(2), 90-93. https://doi.org/https://doi.org/10.14710/jgi.6.2.90-93

Jannah, M., \& Utami, T. N. (2018). Faktor yang Memengaruhi Terjadinya Obesitas pada Anak Sekolah di SDN 1 Sigli Kabupaten Pidie. Jurnal Kesehatan Global, 1(3), 110. https://doi.org/10.33085/jkg.v1i3.3928

Livana, P., Susanti, Y., \& Septianti, I. (2018). Gambaran Pola Asuh Orangtua pada Anak Usia Sekolah dengan Obesitas. Community of Publishing in Nursing (COPING), 6(1), 57-60. https://ocs.unud.ac.id/index.php/coping/article/view/53104

Maesarah, M., Dajafar, L., \& Adam, D. (2019). Eating Patterns and the Incidence of Obesity in Elementary School Children in Gorontalo. Ghidza: Jurnal Gizi Dan Kesehatan, 3(2), 55-58. https://doi.org/https://doi.org/10.22487/ghidza.v3i2.22

Maharani, S., \& Hernanda, R. (2020). Faktor yang Berhubungan dengan Kejadian Obesitas pada Anak Usia Sekolah. Jurnal Ilmiah Multi Science Kesehatan, 12(2), 285-299. http://jurnal.stikes-aisyiyahpalembang.ac.id/index.php/Kep/article/view/513/0

Miranda, T., Yuliani, N. N. S., \& Widiarti, A. (2020). Hubungan antara Asupan Makronutrien dengan Kejadian Overweight dan Obesitas pada Anak Usia 6-12 Tahun di Kota Palangka Raya. Jurnal Kedokteran Universitas Palangka Raya, 8(2), 1032-1039. https://e-journal.upr.ac.id/index.php/JK/article/view/2038

Noviyani, E. P., Jayatmi, I., \& Herliana, I. (2018). Hubungan Peran Orang Tua dan Pola Asuh Makan terhadap Perkembangan Balita. Jurnal Ilmiah Kebidanan Indonesia, 8(1), 1-7. https://doi.org/10.33221/jiki.v8i1.86

Rompas, R., Ismanto, A. Y., \& Oroh, W. (2018). Hubungan Peran Orang Tua dengan Perilaku Hidup Bersih dan Sehat Anak Usia Sekolah di SD Inpres Talikuran Kecamatan Kawangkoan Utara. Jurnal Keperawatan, 6(1). https://ejournal.unsrat.ac.id/index.php/jkp/article/viewFile/19484/19035

Sety, J., Meri, N., \& Fitra, Y. (2021). Promosi Kesehatan Keluarga dalam Pencegahan Obesitas pada Anak Usia 6-12 Tahun. Jurnal Penelitian Kesehatan Suara Forikes, 12, 9-17. http://forikes-ejournal.com/index.php/SF/article/view/1279

Setyawati, A., Ngo, T., Padila, P., \& Andri, J. (2020). Obesity and Heredity for Diabetes Mellitus among Elderly. JOSING: Journal of Nursing and Health, 1(1), 26-31. https://doi.org/https://doi.org/10.31539/josing.v1i1.1149

Suryamulyawan, K. A., \& Arimbawa, I. M. (2019). Prevalensi dan Karakteristik Obesitas pada Anak di Sekolah Dasar Saraswati V Kota Denpasar Tahun 2016. Intisari Sains Medis, 10(2), 342-346. https://doi.org/10.15562/ism.v10i2.393 